\title{
The Molecular Basis of Increased Glomerulosclerosis after Blockade of the Renin Angiotensin System in Growth Hormone Transgenic Mice
}

\author{
Emmanuel P. Peten,* Liliane J. Striker,* Agnes Fogo, ${ }^{\dagger}$ \\ Iekuni Ichikawa, ${ }^{\dagger}$ Aneeta Patel,* and Gary E. Striker* \\ *Renal Cell Biology Section, Metabolic Diseases Branch, National \\ Institute of Diabetes and Digestive and Kidney Diseases, Bethesda, \\ Maryland, U.S.A. \\ ${ }^{\dagger}$ Department of Pediatrics and Pathology, Vanderbilt University School \\ of Medicine, Nashville, Tennessee, U.S.A.
}

\begin{abstract}
Background: Angiotensin converting enzyme inhibitor (ACEi) therapy delays the onset of renal failure in diabetic nephropathy and inhibits or delays the onset of proteinuria in several animal models.

Materials and Methods: We examined this question using a transgenic model of chronic glomerulosclerosis caused by an excess production of growth hormone $(\mathrm{GH})$ in which there is progressive glomerular scarring leading to uremia. In addition, since $\mathrm{GH}$ mice do not have systemic hypertension or an elevated glomerular filtration rate, we could address the question of whether ACEi or angiotensin II receptor antagonists (AII RA) had an effect on the development of glomerulosclerosis under these conditions. Since excess matrix accumulates in glomerulosclerosis because of alterations in the balance between its synthesis and degradation, we examined the effect of ACEi and AII RA on these parameters.
\end{abstract}

Results: Systemic blood pressure was unaffected by ACEi treatment, but the glomerular filtration rate decreased $85 \%$. ACEi-treated mice had increased mesangial deposition of type I collagen and decreased 105 $\mathrm{kD}$ complex collagenase activity. In addition, ACEitreated GH mice had increased glomerular $\alpha$ l type I collagen, $\alpha$ l type IV collagen, and $\alpha$-smooth muscle cell actin mRNAs. No changes were noted in $\beta$ actin, or $72 \mathrm{kD}$ metalloproteinase mRNAs. The result of these changes was a net increase in sclerosis. Surprisingly, GH mice treated with ACEi or AngII RA developed marked renal arteriolar lesions.

Conclusions: In some forms of glomerulosclerosis, the lesions develop independently of angiotensin II. Pharmacological inhibition of angiotensin II, in this circumstance, may aggravate the lesions through disregulation of the levels and the balance between glomerular matrix synthesis and degradation.

\section{INTRODUCTION}

Angiotensin converting enzyme inhibitor (ACEi) therapy delays the onset of end-stage renal failure in patients with diabetic nephropathy (1) and prevents or attenuates the development of proteinuria and renal lesions in rats with 5/6

Address correspondence and reprint requests to: Liliane J. Striker, Building 10, room $3 \mathrm{~N} 110$, National Institutes of Health, Bethesda, Md 20892, U.S.A. nephrectomy $(2,3)$ and streptozotocin-induced diabetes (4). Since angiotensin II receptor antagonists (AngII RA) have a comparable effect (5), it has been postulated that the renin angiotensin system (RAS) may play a role in the development of glomerulosclerosis. Since ACEi therapy did not consistently modify the course of glomerulosclerosis in adriamycin- and aminonucleoside-treated rats $(6-8)$, we thought it important to determine the molecular effects of RAS block- 
TABLE 1. Oligonucleotides and PCR product size for seven target genes

\begin{tabular}{llll}
\hline Species & \multicolumn{1}{c}{ 5' Primers } & \multicolumn{1}{c}{ 3' Primers } & Size \\
\hline$\alpha 1$ IV Collagen & TAGGTGTCAGCAATTAGGCAGG & CGGACCACTATGCTTGAAGTGA & 484 \\
$\alpha 2$ IV Collagen & ACTCATTCCAACCGTCTGTCAGC & GCAAATCATTGACAGTGGCGTCTA & 562 \\
$\alpha 11$ Collagen & TGGTCCTCTGGAAATGCTGACC & CAGGAGAACCAGGAGAACCAGG & 297 \\
$\alpha$ SMC Actin & CCTGACGGACTACCTCATG & CAAATCAAAGCTTTGGGCAG & 434 \\
$\beta$ Actin & TCTAGGCACCAAGGTGT & TCATGAGGTAGTCCGTAGG & 460 \\
72 kD Gelatin & CTTTGCAGGAGACAAGTTCTGG & TTAAGGTGGTGAGGTATCTGG & 701 \\
bovine GH & GAGGAACTGAGGAGTTCAGC & TCCACTGCCATCCAACAACC & 395 \\
\hline
\end{tabular}

ade on glomerulosclerosis induced by excess growth factors. Therefore, we examined mice transgenic for bovine growth hormone (GH), since the molecular basis of the glomerular lesion had been studied (9). In this model the renal lesions lead to death in uremia and the animals are not hypertensive. Another reason for selecting this model is that GH has been shown to be a requirement for the development of glomerulosclerosis in both mice and rats (10). Finally, the $\mathrm{GH}$ effect is not mediated through excess body growth, since mice transgenic for a mutant $\mathrm{GH}$ are of normal size but develop glomerulosclerosis (11). The glomerular lesions in GH mice are characterized by activation of several genes coding for extracellular matrix (ECM) components $(12,13)$. These changes could be mediated by a direct effect of AngII on glomerular cells, since exposure of mesangial cells to AngII in vitro results in increased collagen synthesis $(14,15)$.

Since most patients have established renal disease when they come to medical attention, we studied mice treated with ACEi or AngII RA after the onset of glomerulosclerosis. Since glomerulosclerosis may result from an imbalance between matrix synthesis and degradation, we explored the effect of RAS blockade on both processes. Glomerular $\alpha$ l type I collagen, $\alpha$ l type IV collagen, and $\alpha$-smooth muscle cell (SMC) actin mRNAs were increased in treated GH mice. Type I collagen deposition in the mesangium was increased and $105 \mathrm{kD}$ complex collagenase activity was decreased. Thus, there were changes in both the synthesis and degradation of ECM components, resulting in a net increase in glomerulosclerosis.

\section{MATERIALS AND METHODS}

Drugs, Mice, and Treatment Protocols

Captopril (from Bristol-Myers-Squibb, Princeton, NJ, U.S.A.) and the AngII RA, L-158,809 (from Merck Sharp \& Dohme, Rahway, NJ, U.S.A.) were gifts. GH mice were treated from age 6 to 12 weeks with either captopril (GHACEi, $150 \mathrm{mg} / \mathrm{kg} /$ day, $\mathrm{GH}=13$ ) or with the AngII receptor antagonist L-158,809 (GH-AngII $\mathrm{RA}, 20 \mathrm{mg} / \mathrm{kg} /$ day, $\mathrm{GH}=7$ ). Both were given daily in drinking water. Control, age-matched GH mice (GH-Ctrl, $n=12$ ) drank regular water. Additional controls consisted of non-transgenic age-matched normal SJL/C57Bl Fl mice treated with $150 \mathrm{mg} / \mathrm{kg} /$ day of captopril (WT-ACEi, $n=$ 5) or regular water (WT-Ctrl, $n=8$ ). Transgenic animals were identified by PCR analysis performed on detergent-extracted material from tail biopsies, using specific primers for bovine growth hormone cDNA that did not cross-react with the mouse sequence (Table 1 ).

\section{Serum Creatinine, Urine Albumin, and Creatinine}

Albumin and creatinine were measured in spot urine samples. Albumin was determined by a modified enzyme-linked immunoabsorbent assay, as previously described (9). Creatinine concentration was measured by a colorimetric method (Stanbio Lab, San Antonio, TX, U.S.A.).

\section{Blood Pressure and Glomerular Filtration Measurement}

Mice were anesthetized with Inactin (Byk, Gulden Konstanz, Germany; $200 \mathrm{mg} / \mathrm{kg} \mathrm{BW,} \mathrm{i.p.)} \mathrm{for}$ 
measurements of kidney function, as previously described in rats (16). Briefly, following tracheotomy, in-dwelling polyethylene catheters (PE10, Clay Adams, Parsippany, NJ, U.S.A.) were placed into the left jugular vein for infusion of plasma, inulin, and para-aminohippurate (PAH), and the left carotid artery was cannulated to monitor mean systemic arterial pressure (MAP). After priming doses of $0.2 \mathrm{ml}$ of plasma and 0.2 $\mathrm{ml}$ of the inulin/PAH solution $(3.6 \% \mathrm{v} / \mathrm{v}$ and $0.4 \% \mathrm{v} / \mathrm{v}$, respectively), maintenance infusions were continued at $0.5 \mathrm{ml} / \mathrm{hr}$ for both plasma and inulin/PAH to maintain euvolemia. MAP was measured directly with a pressure transducer system as previously described (2). The bladder was cannulated with PE-50, and after steadystate urine flow was present, two consecutive timed collections of urine samples were obtained through bladder cannulations for determination of urine flow rate and inulin and PAH concentrations. Arterial blood was collected into capillary tubes for determination of plasma inulin and PAH concentrations at the midpoint of urine collection. Glomerular filtration rate and renal plasma flow were then estimated by inulin and $\mathrm{PAH}$ clearance, respectively. Inulin concentrations in plasma and urine were determined by the macroanthrone method (17). PAH concentrations in plasma and urine were assayed by the method of Bratton and Marshall, modified by Smith et al. (18). Micropuncture measurement of glomerular capillary pressure was not performed in these mice since they did not have superficial glomeruli.

\section{Light and Immunofluorescence Microscopy}

Coronal kidney sections were fixed in Carnoy's fixative and embedded in paraffin. Five-micron sections were stained with periodic acid-Schiff and hematoxylin/eosin. Unstained sections were deparaffinized and coated with rabbit antimouse type IV collagen (Collaborative Research Inc., Bedford, MA, U.S.A.) or rabbit antimouse type I collagen (Chemicon International Inc, Temecula, CA, U.S.A.), followed by biotin-conjugated goat antirabbit IgG (Tago, Burlingame, CA, U.S.A.) and streptavidin-conjugated fluorescein isothiocyanate (Zymed Laboratories, San Francisco, CA, U.S.A.) (12).

\section{Renin and TGF- $\beta$ Immunostaining}

Sections of kidneys fixed in aqueous Bouin's solution and embedded in low melting point paraffin were immunostained using a 1:1,000 dilution of a rabbit polyclonal antimouse renin antibody (gift of Drs. P. Corvol and J. Gasc, Laboratoire de Médecine Expérimentale, Collège de France, Paris, France). Affinity-purified rabbit polyclonal antibodies directed against peptide sequences unique to TGF- $\beta 1$, TGF- $\beta 2$, and TGF- $\beta 3$ (gift of Dr. K. Flanders, Laboratory of Chemoprevention, National Cancer Institute, Bethesda, MD, U.S.A.) were used as previously reported (19). Immunostaining was performed using an immunoperoxidase Vectastain kit (Vector Laboratories Inc., Burlingame, CA, U.S.A.). Negative controls, included in each experiment, consisted of replacement of the primary antibody by preimmune rabbit serum or by an equivalent concentration of nonimmune rabbit IgG. The specificity of TGF- $\beta$ isoforms staining was assessed by demonstrating complete blocking in the presence of a 20 -fold molar excess of the immunizing peptide.

\section{Autoradiography and Morphometry}

Autoradiography was performed as previously described (20). Body weight, $1 \mu \mathrm{Ci} / \mathrm{gm}$, of $\left[{ }^{3} \mathrm{H}\right]$ thymidine in $200 \mu \mathrm{l}$ of saline was given intraperitoneally and animals were sacrificed 16-18 hr later. Kidney sections were deparaffinized, coated with Kodak NTB-3 emulsion (International Biotechnology Inc., New Haven, CT, U.S.A.), and exposed for 3 weeks at $4^{\circ} \mathrm{C}$ in the dark. The thymidine labeling index (TLI) was expressed as the percentage of labeled cells found by examining 50 glomerular profiles/animal. The mean glomerular cross-sectional area was measured with a computer-assisted planimeter in 100 successive glomeruli/mouse. The mean glomerular volume was calculated from the harmonic mean of the glomerular equatorial area, using the method of De Hoff and Rhines for mean size of particles of similar shape (21).

\section{Isolation of Glomeruli and Reverse Transcription}

Glomeruli were isolated by microdissection in the presence of RNase inhibitors as previously described (22). Briefly, after sacrificing the mouse by decapitation, the lower pole was isolated and snap frozen on dry ice for zymography 
TABLE 2. GH mice treated with ACEi and AngII RA from age 6 to 12 weeks

\begin{tabular}{lccc}
\hline Parameters (Units) & GH-Ctrl & GH-ACEi & $\begin{array}{c}\text { GH-AngII } \\
\text { RA }\end{array}$ \\
\hline Body Weight $(\mathrm{g})$ & $47.6 \pm 2.5$ & $44.0 \pm 1.7$ & $45.1 \pm 3.7$ \\
Body Weight Increase $(\%)$ & $143 \pm 11$ & $144 \pm 4$ & $148 \pm 17$ \\
Kidney Weight $(\mathrm{mg})$ & $467 \pm 29$ & $364 \pm 26^{a}$ & $429 \pm 39$ \\
Ratio KW/BW $\left(\times 10^{-2}\right)$ & $98 \pm 4$ & $83 \pm 5^{b}$ & $95 \pm 7$ \\
Serum Creatinine $(\mathrm{mg} / \mathrm{dl})$ & $0.60 \pm 0.10$ & $0.59 \pm 0.07$ & $0.37 \pm 0.09$ \\
Urine Alb./Creat. $\left(10^{-2} \mu \mathrm{g} / \mathrm{mg}\right)$ & $4.12 \pm 0.96$ & $4.34 \pm 0.85$ & $4.43 \pm 1.21$ \\
Glomerular Volume $\left(10^{5} \mu \mathrm{m}^{3}\right)$ & $24.84 \pm 0.85$ & $24.02 \pm 1.60$ & $22.93 \pm 1.63$ \\
Thymidine Labeling Index $(\%)$ & $2.4 \pm 0.3$ & $3.5 \pm 0.2^{c}$ & $3.3 \pm 0.3^{d}$ \\
\hline
\end{tabular}

${ }^{a} p=0.02,{ }^{b} p=0.03,{ }^{c} p=0.006,{ }^{d} p=0.04$, all comparisons versus $\mathrm{GH}-\mathrm{Ctrl}$.

analyses. The left kidney was first perfused with saline and then by a collagenase solution containing soluble RNase inhibitors. After collagenase digestion, 40-60 glomeruli were isolated at $4^{\circ} \mathrm{C}$ in the presence of vanadyl ribonucleoside complex for reverse transcription (RT). RT was performed as previously described (22) except that the glomeruli were freeze thawed once in acetone dry ice and sonicated at $4^{\circ} \mathrm{C}$ for $5 \mathrm{~min}$ in the presence of $2 \%$ Triton and $4 \mathrm{U} / \mu \mathrm{l}$ of human placenta derived RNase inhibitor (Boehringer Mannheim, Indianapolis, IN, U.S.A.) just before adding the RT components. The samples were continuously cooled during sonication (Micro Ultrasonic Cell Disrupter, Kontes, Vineland, NJ, U.S.A.). The optimal conditions for cDNA recovery from permeabilized and sonicated glomeruli were determined in preliminary experiments (data not shown).

\section{PCR Assays}

Primers (Table 1) for mouse $\alpha$ IIV, $\alpha 2$ IV, and $\alpha 1 \mathrm{I}$ collagen, $\alpha$ SMC actin, $\beta$ actin, and 72 kD metalloproteinase mRNAs, and for bovine growth hormone genomic DNA, which had been previously developed, were synthesized on a PCRMate (Applied Biosystems, Foster City, CA, . U.S.A.). The identity of each amplified product was assessed by size and by restriction enzyme analysis. The specificity of these primers for mRNA was determined by performing PCR on reverse transcribed glomeruli in which the reverse transcriptase enzyme was omitted. PCR was performed as previously described (22) us- ing the GeneAmp DNA Amplification Kit (Perkin Elmer Cetus, Norwalk, CT, U.S.A.). Competitive PCR assays had been previously developed for $\alpha$ IIV and $\alpha 2$ IV collagen, $\alpha$ SMC actin, $\beta$ actin, and $72 \mathrm{kD}$ metalloproteinase cDNAs by constructing a cDNA mutant for each molecule, with a small internal deletion or a new restriction enzyme site. Analysis of PCR products was performed using a PDI densitometer loaded with a Quantity One $^{R}$ image analysis software (PDI, Huntington Station, NY, U.S.A.). Competitive PCR assays were performed in duplicate or triplicate.

\section{Statistical Analysis}

The unpaired Student's $t$-test, with the Welch approximation method, was used for comparisons between groups and a $p$ value $<0.05$ was considered significant. All data are expressed as mean \pm SEM.

\section{RESULTS}

\section{Body Growth, Kidney Weight, Urine Creatinine, and Urine Albumin}

At 6 weeks, there were no significant differences in body weight (BW) between treated and untreated GH mice, thus high doses of ACEi and of AngII RA were well tolerated (Table 2). The kidney weight $(\mathrm{KW})$ in GH-ACEi mice was $22 \%$ lower than in GH-ctrl or GH-AngII RA mice, resulting in a lower $\mathrm{KW} / \mathrm{BW}$ ratio. The urine 

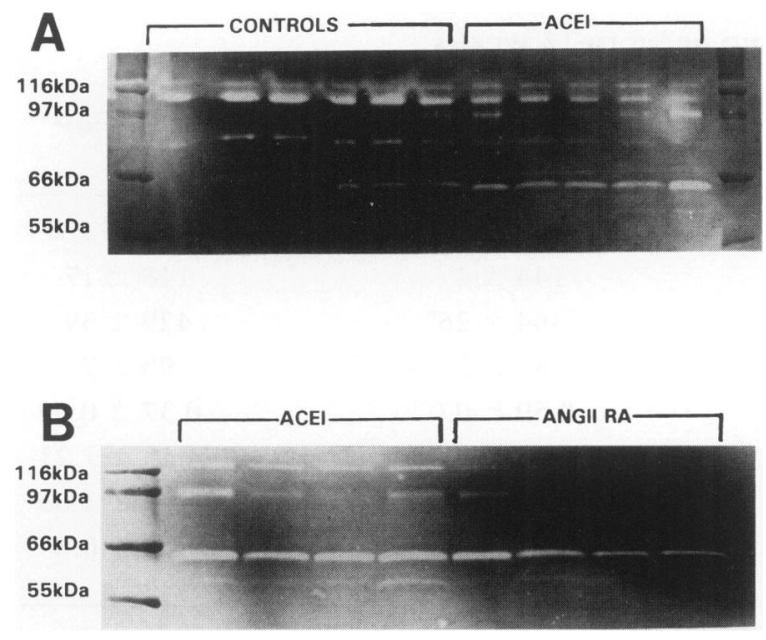

FIG. 1. Zymogram

(A) Ten percent SDS-PAGE gelatinase activity analysis from six GH-Ctrl versus five ACEi mice. Molecular size standards are indicated on the left. The absence of the lower gelatinase band in the first three animals is due to a technical artifact in the gel (presence of an air bubble). (B) Comparison of gelatinase activity between four GH-ACEi and four GH-AngII RA-treated mice.

albumin/creatinine ratio was increased in untreated GH mice (9), but was not influenced by ACEi or AngII RA therapy (Table 2). Serum creatinine was not different between the three groups.

\section{GFR and Blood Pressure}

Direct measurement of intra-arterial blood pressure revealed no significant differences between WT-Ctrl mice (119 $\pm 5 \mathrm{~mm} \mathrm{Hg}, n=5)$, GH-Ctrl mice (99 $\pm 19 \mathrm{~mm} \mathrm{Hg}, n=2$ ), and GH-ACEi mice ( $89 \pm 9 \mathrm{~mm} \mathrm{Hg}, n=3$ ) in 12 week animals (Fig. 1). The inulin clearance in GH-Ctrl mice $(0.43 \pm 0.10 \mathrm{ml} / \mathrm{min}, n=3)$ did not differ from WT-Ctrl $(0.52 \pm 0.14 \mathrm{ml} / \mathrm{min}, n=4)$, nor did the PAH clearance $(\mathrm{GH}-\mathrm{ctrl}=1.33 \pm 0.55 \mathrm{ml} / \mathrm{min}$, $n=4$; versus WT-Ctrl $=1.42 \pm 0.16 \mathrm{ml} / \mathrm{min}$, $n=3)$. However, there was an $85 \%$ reduction in GFR in GH-ACEi mice $(0.06 \pm 0.03 \mathrm{ml} / \mathrm{min}, n=$ 4). PAH clearance, which could be measured in only one GH-ACEi animal, was reduced $(0.15$ $\mathrm{ml} / \mathrm{min}$ ).

\section{Glomerulosclerosis, Vascular Lesions}

There was no apparent difference in the severity of the light microscopic glomerular lesions in
GH-ACEi, GH-AII RA, or GH-Ctrl mice (Fig. 2). All treated mice developed juxtaglomerular apparatus. (JGA) hypertrophy and conspicuous arteriolar changes directly adjacent to the JGA, consisting of intimal and medial hypercellularity, which considerably narrowed the lumen of both afferent and efferent arterioles (Fig. 2). There were no thrombotic or necrotic glomerular lesions, even in the vicinity of the arteriolar lesions. To determine whether the vascular lesions were related to the presence of high levels of $\mathrm{GH}$ in transgenic mice, five normal littermate mice were treated with ACEi, at the same dose, for 6 weeks. While vascular changes with the same distribution as in GH-ACEi and GH-AngII RA mice were observed, they appeared less severe (Fig. 3).

To determine if the lesions were due to the high drug dosage used in this study, five 6-weekold GH mice were given 1/10th the dose (15 $\mathrm{mg} / \mathrm{kg} /$ day) for 6 weeks. The vascular lesions were identical to animals given the higher ACEi doses (data not shown).

Type I collagen was increased in the glomeruli of GH-ACEi and GH-AngII RA mice, compared with $\mathrm{GH}-\mathrm{Ctrl}$ by immunofluorescence microscopy (Figs. 4A and 4B). The increased deposition was concentrated in the zone close to the vascular pole of the glomerular tuft. The affected arterioles also contained large amounts of type I collagen in their walls (Fig. 4B), whereas normal afferent and efferent arterioles resembled controls.

The intensity and distribution of glomerular type IV collagen immunostaining did not differ between treated and control GH mice and was not increased in the vascular lesions (data not shown).

\section{Glomerular TLI and Glomerular Volume}

There was a 1.4-fold increase in the glomerular TLI of GH mice treated with either ACEi or AngII RA (Table 2). There was no increase in the number of $\left[{ }^{3} \mathrm{H}\right]$-thymidine-labeled smooth muscle cells within the affected arterioles. Neither drug regimen influenced the glomerular volume of GH mice (Table 2).

\section{Gelatinase Activity}

Gelatinase activity was detected by zymography at three main sites in WT-Ctrl mice (Fig. 1A): approximately at $65 \mathrm{kD}$, which is within the molecular size range previously described for the 

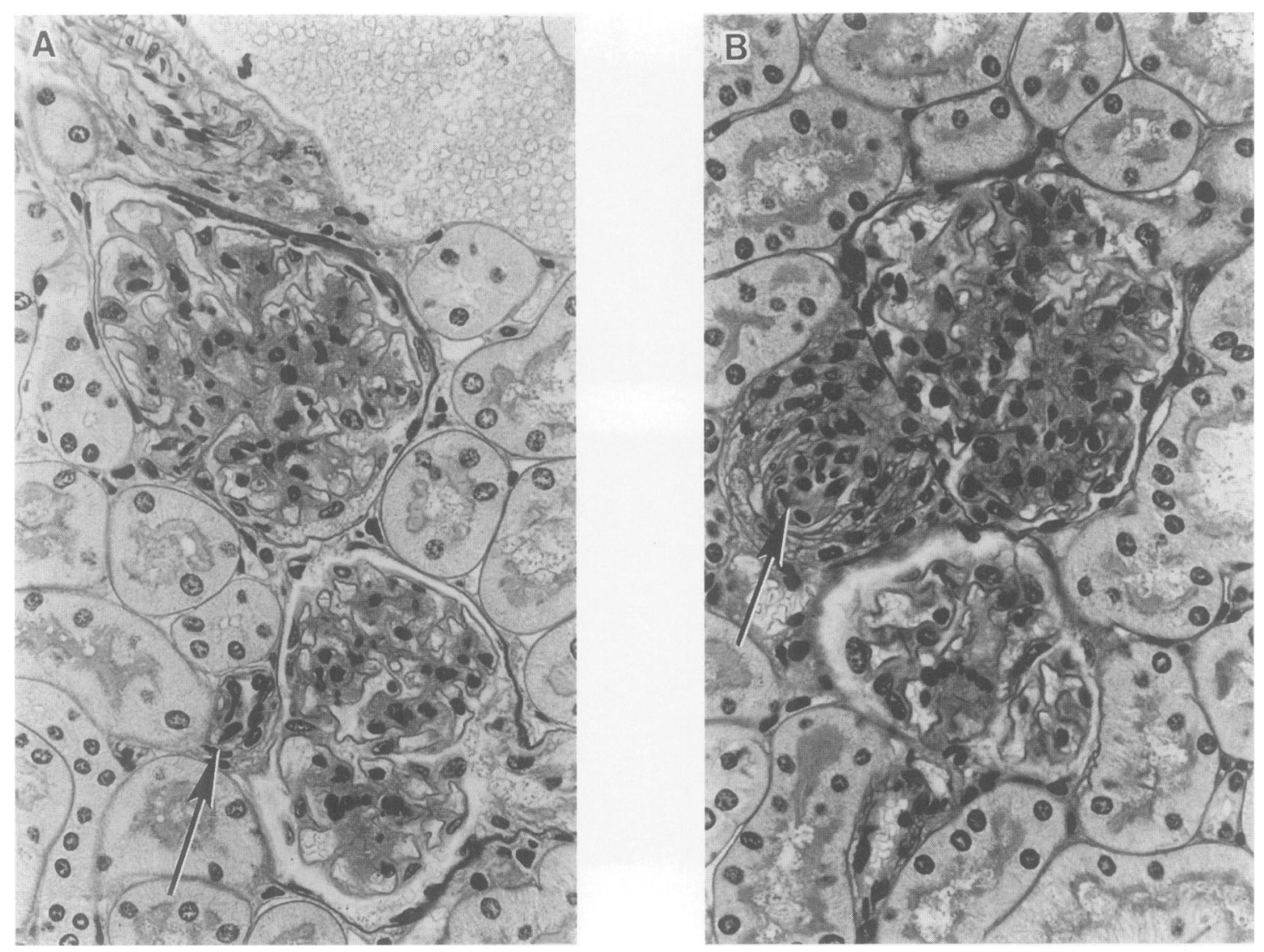

FIG. 2. Histology in Adult GH Mice after Six Weeks of Treatment

PAS stained sections from GH mice treated from 6 to 12 weeks of age with water (A), or captopril (B). There was no effect on glomerulosclerosis and the treated mice developed juxtaglomerular vascular lesions (arrows). Similar lesions were observed with AngII RA treatment.

$72 \mathrm{kD}$ gelatinase, at $75 \mathrm{kD}$, and at $105 \mathrm{kD}$ as found previously (23). The latter presumably corresponded to the latent $92 \mathrm{kD}$ complex. There was also weak gelatinase activity at approximately $120 \mathrm{kD}$ and $97 \mathrm{kD}$. There was a decrease (Fig. 1A), or disappearance (Fig. 1B), of the 105 $\mathrm{kD}$ and the $75 \mathrm{kD}$ gelatinase activity, but no change in the $97 \mathrm{kD}$ activity in GH-ACEi or GHAngII RA mice. There was no difference in the $120 \mathrm{kD}$ and in the $65 \mathrm{kD}$ activity between GH$\mathrm{Ctrl}$ and GH-ACEi mice, but there was a decrease in the activity of the $120 \mathrm{kD}$ complex in GHAngII RA mice (Fig. 1B and Table 3).

\section{$\alpha 1 I V$ and $\alpha 11$ Collagen and $\alpha$ SMC Actin mRNA Levels}

$\alpha$ IIV collagen and $\alpha$ SMC actin mRNA levels were elevated in GH-ACEi mice, 2- and 1.8-fold, respectively (Fig. 5). There was no difference between GH-control and treated GH mice in the levels of $\alpha 2 \mathrm{IV}$ collagen, $\beta$ actin, and $72 \mathrm{kD}$ metalloproteinase mRNAs (data not shown). $\alpha 1$ I collagen mRNA levels were increased in both $\mathrm{GH}$ ACEi and GH-AII RA mice (Fig. 4A).

\section{Renin Immunostaining in JGAs and Vascular Lesions}

Renin was present in the JGAs of GH-Ctrl mice, and the intensity or distribution was not significantly different from that in WT-Ctrl mice. Renin immunostaining was considerably more intense in all treated mice (Fig. 6). The JGAs appeared hypertrophied and contained an increased amount of renin in both treatment groups. There was an extension of renin-positive arteriolar smooth muscle cells toward the interlobular arteries. Renin was not detected in glomeruli, ex- 

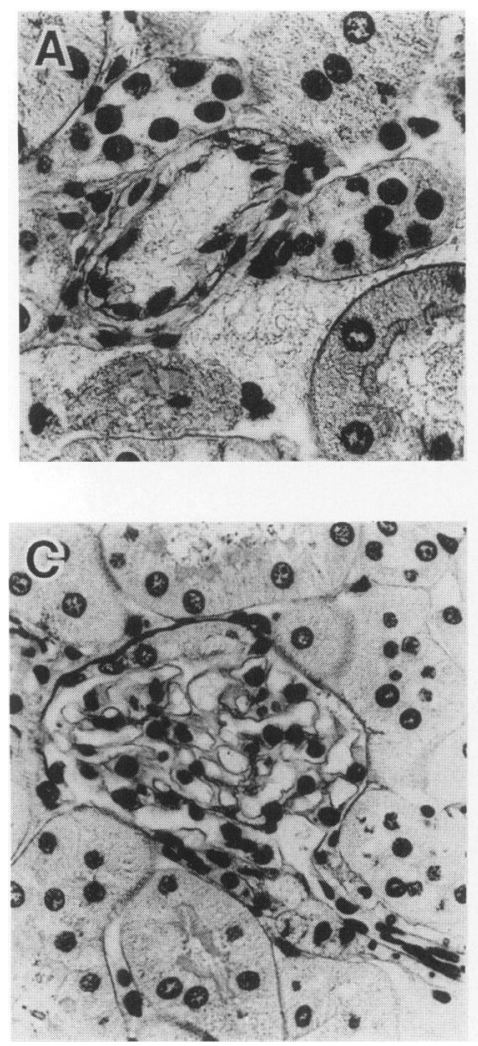
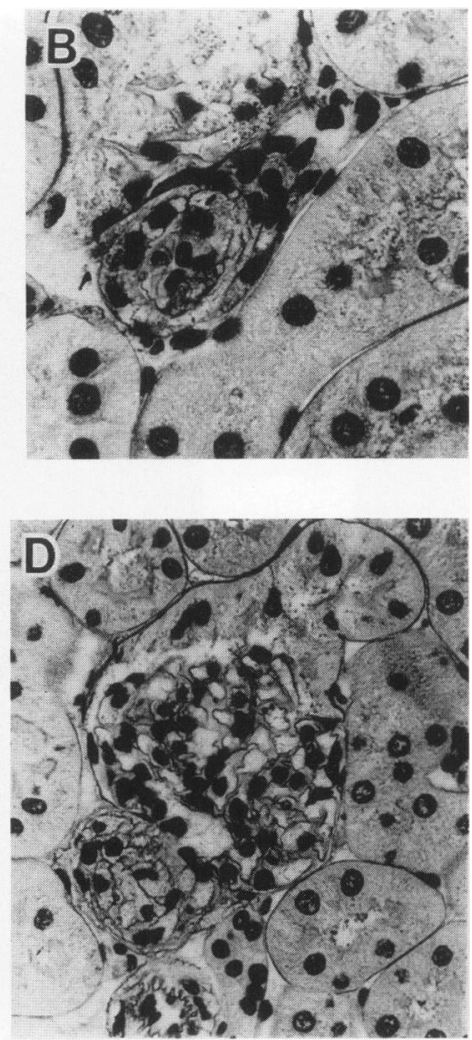

FIG. 3. Histology in Adult WT Mice after 6 Weeks of Treatment

PAS stained kidney sections from WT mice treated from 6 to 12 weeks of age with water (left) or captopril (right). (Top) Interlobular artery showing medial hypercellularity (B) compared with a normal vessel (A). (Bottom) Glomerulus displaying a hypertrophic JGA with an abnormal afferent arteriole (D) compared with a normal glomerulus (C).

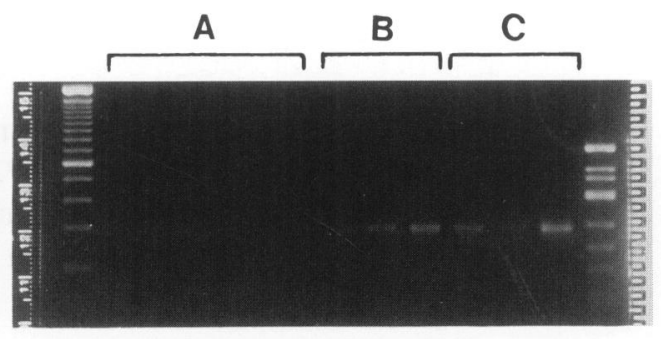

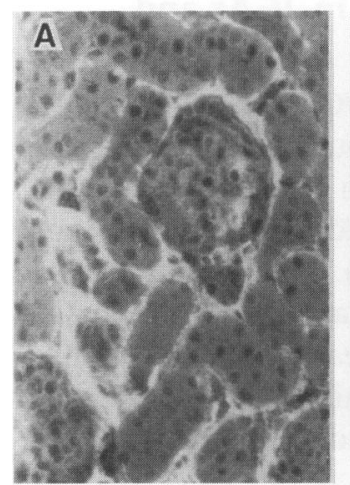
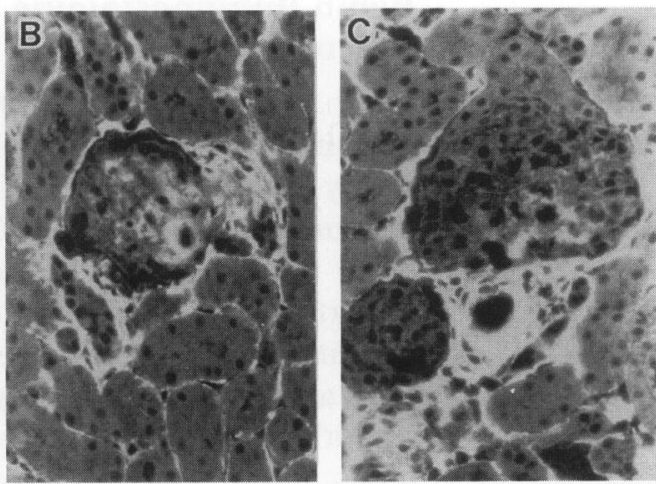

FIG. 4. Type I Collagen mRNA and Peptides, GH Glomeruli

(Top) RT-PCR on isolated glomeruli for $\alpha$ II collagen mRNA: cDNA was amplified from five $\mathrm{GH}-\mathrm{Ctrl}$ (A), three GH-ACEi (B), and three AngII RA (C)-treated mice. Under the PCR conditions selected (40 PCR cycles on $1 / 10$ th of glomerular cDNA as template) $\alpha 1$ I collagen mRNA was barely detectable in $\mathrm{GH}-\mathrm{Ctrl}$ mice. Under these conditions, $\alpha$ II collagen mRNA levels were elevated by both treatments. (Bottom) Immunostaining for type I collagen on kidney sections of $\mathrm{GH}$ mice treated with water (A), captopril (B), and L158,809 (AngII RA) (C). Type I collagen deposition was increased in the glomeruli of the treated GH mice and in the adjacent juxtaglomerular arterial lesions. 
TABLE 3. Effect of ACEi and AngII RA treatment on collagenase activity

\begin{tabular}{lccc}
\hline $\begin{array}{l}\text { Molecular } \\
\text { Weight } \\
\text { (kD) }\end{array}$ & GH-Ctrl & GH-ACEi & GH-AngII RA \\
\hline 120 & \pm & \pm & $\downarrow$ \\
105 & + & $\downarrow$ & $\downarrow$ \\
97 & \pm & \pm & \pm \\
75 & + & $\downarrow$ & $\downarrow$ \\
65 & + & + & + \\
\hline
\end{tabular}

cept occasionally in the immediate vicinity of the vascular pole in any group.

\section{TGF- $\beta$ Immunostaining}

TGF- $\beta 1, \beta 2$, and $\beta 3$ staining was prominent in proximal tubules and in smaller amounts in vascular walls and glomeruli. There was no change in TGF- $\beta 1, \beta 2$, or $\beta 3$ staining in the kidneys of treated GH mice. Interestingly, the hypertrophied JGA and the vascular lesions contained a similar staining density for each of the three TGF- $\beta$ isoforms.

\section{DISCUSSION}

The role of the RAS system in the development and the progression of glomerular diseases has attracted considerable attention, since ACEi treatment appears to prevent the development or progression of glomerular lesions in some animal models $(3,4,24-27)$. In addition, ACEi therapy prolongs the time to doubling of the serum creatinine in type I diabetics with advanced nephropathy (1). ACEi has been postulated to have renoprotective effects that are separate from its vasopressor actions on the glomerulus, especially at high (10-fold) doses (27). At this high level the local glomerular RAS may be inhibited, preventing mesangial cell activation and glomerular hypertrophy (28).

The current study was undertaken to examine the potential role of AII in a model of growth factor-induced glomerulosclerosis. Six-week-old GH mice were given ACEi or AngII RA for a period of 6 weeks. At 12 weeks, untreated GH mice had a normal glomerular filtration rate and blood pressure, but had glomerulosclerosis with elevated levels of glomerular types I and IV collagen mRNAs, as well as an increased glomerular cell turnover rate. While systemic blood pressure in ACEi GH mice did not differ from either normal littermates or untreated GH mice, their GFR was reduced by $85 \%$. Neither treatment affected body weight increase, serum creatinine, urine albumin/creatinine ratio, or glomerular volume.

The glomerular lesions in ACEi or AngII RAtreated GH mice were not attenuated and differed from one another. In both groups there was an increase in the glomerular labeling index, the deposition of type I collagen by immunofluorescence microscopy, and the levels of type I collagen mRNA. There was also decreased 105 $\mathrm{kD}$ and $75 \mathrm{kD}$ metalloproteinase activity by zy-
FIG. 5. cDNA, Control, and Treated Adult GH Mice

Competitive PCR quantitation of glomerular cDNA for $\alpha$ IIV collagen, $\alpha$ SMC actin, $\alpha 2$ IV collagen, and $\beta$-actin in GH-Ctrl, GH-ACEi, and GH-AngII RA-treated mice ( $n$ $=5$ for each group). Data are expressed as relative units compared with levels in controls ${ }^{*} p=0.01$ for $\alpha$ IIV and 0.007 for $\alpha$ SMC actin versus $\mathrm{GH}-\mathrm{Ctrl}$ ).

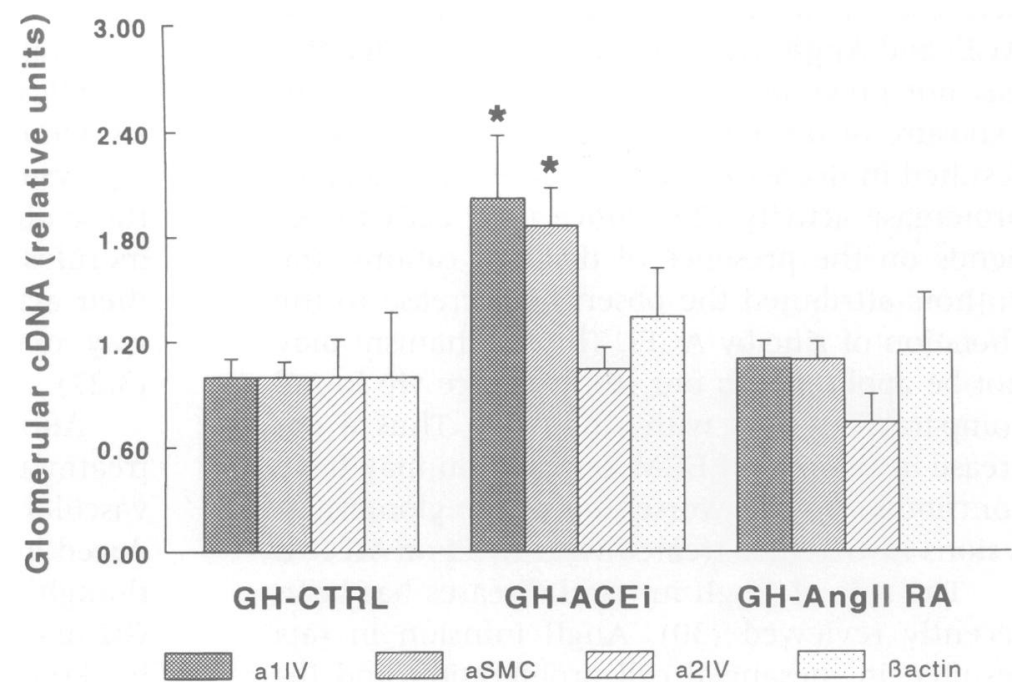



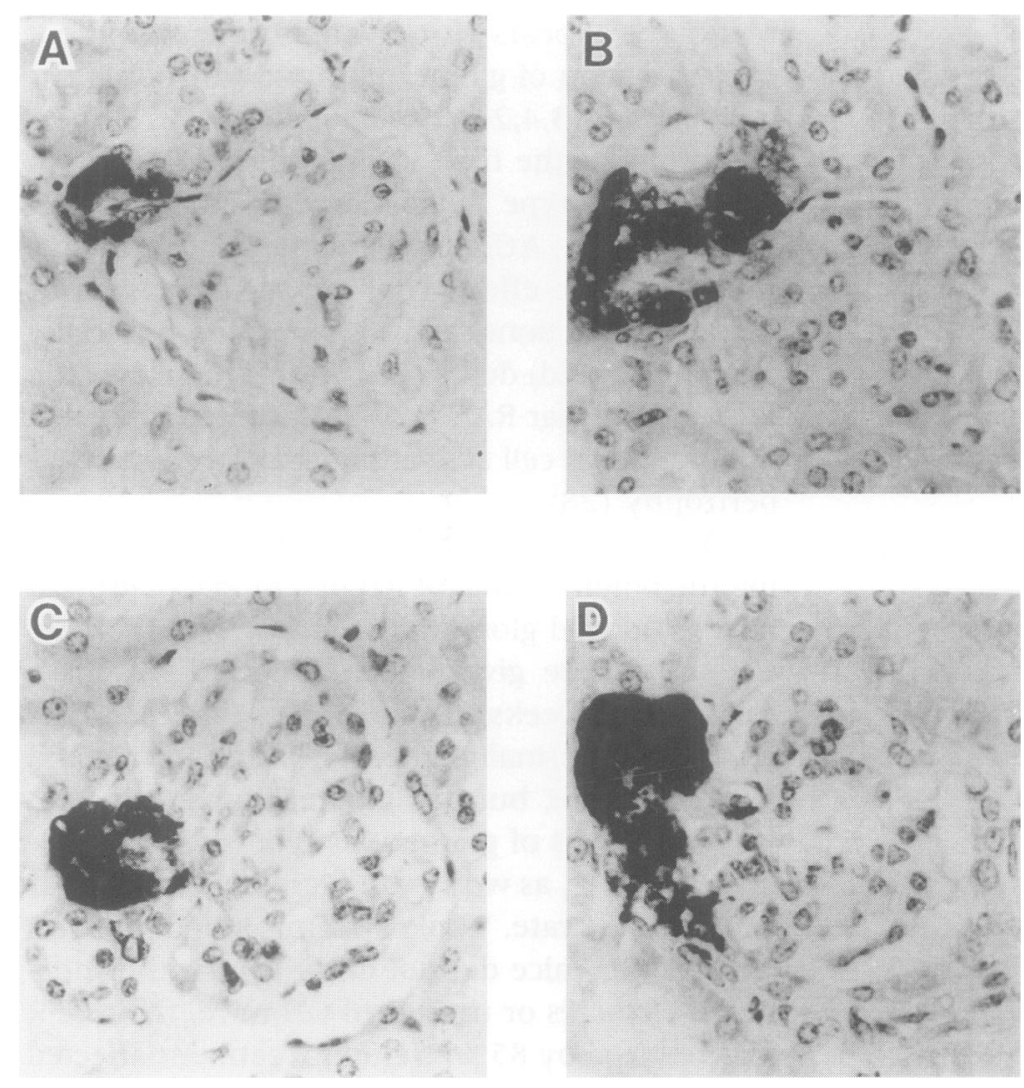

FIG. 6. Renin Immunostaining in Control and Treated Adult GH Mice

Immunoperoxidase staining for renin on sections of GH mice treated from 6 to 12 weeks of age with water (A), high doses of captopril (B), low doses of captopril (C), and high doses of L158,809, an AngII RA. Renin staining is increased in hypertrophic JGAs and in adjacent vascular lesions in all treated mice. mography. Whereas there was a 2 -fold increase in $\alpha$ IIV collagen and $\alpha$ SMC actin mRNAs in GH mice treated with ACEi, neither were increased in AngII RA mice. Since the $\alpha 1 \mathrm{IV}$ and $\alpha \mathrm{SMC}$ actin mRNA levels were not elevated in AngII RA mice, the mRNA increase in ACEi GH mice may have resulted from potentiation of a local bradykinin effect.

An intriguing finding in this study was the decrease in metalloproteinase activity in both ACEi and AngII RA mice. To our knowledge this has not previously been described in vivo, but exposure of rat mesangial cells in vitro to ACEi resulted in decreased $72 \mathrm{kD}$ and $92 \mathrm{kD}$ metalloproteinase activity (29). Since their activity depends on the presence of divalent cations, the authors attributed the observed decrease to the chelation of zinc by ACEi. This mechanism may not be applicable to our results, since we found comparable results with AngII RA. Thus a decrease in the rate of ECM degradation may have contributed to the worsening of the glomerular lesions in GH mice treated with ACEi or AII RA.

The role of AngII in renal diseases has been recently reviewed (30). AngII infusion in rats resulted in mesangial cell proliferation and in- creased mesangial $\alpha \mathrm{SMC}$ actin expression, a potential marker of mesangial activation (31). The reduction of glomerular lesions in rats treated with ACEi, and more recently with AngII RA, supports the postulate that AngII may play an important role in the development of glomerular injury in some animal models (3-5). The exact mechanisms of action of ACEi are not yet completely elucidated. However, the renoprotective effects of ACEi may occur in the absence of a reduction in systemic blood pressure $(5,27)$ or modifications of local glomerular hemodynamics. Other antihypertensive agents, while reducing systemic blood pressure to levels similar to those obtained with ACEi, failed to prevent glomerulosclerosis. This suggests that this aspect of their action is mediated through another pathway, not shared by other antihypertensive drugs $(3,27)$.

Another consequence of ACEi and AngII RA treatment in GH mice was the development of vascular lesions. Arteriolar lesions were also induced in normal controls treated with ACEi, although they were less marked than in treated GH mice. They consisted of intimal and medial hyperplasia in the afferent and efferent arte- 
rioles close to the hypertrophied JGAs. The severe narrowing of the arterioles and a reduction of efferent arteriolar tone by AII may explain the sharply reduced glomerular filtration rate in treated GH mice. Both ACEi- and AngII RAtreated animals had increased amounts of immunoreactive renin in the hypertrophic JGA regions and in the arteriolar lesions, and this extended toward the interlobular arteries. The accumulation of renin was likely due to the interruption of the negative feedback between AngII and renin production, through the angiotensin type 1 receptor on the JGA cells (32). The mechanism of the vascular lesions is not clear from the present experiments, but the development of comparable lesions in nontransgenic mice rules out a major role for GH. A toxic effect of the high doses of ACEi used is unlikely, since much lower doses resulted in the same lesions. It is also very unlikely that potentiation of the bradykinin system was involved since both ACEi and AngII RA mice had the same vascular changes.

TGF- $\beta 1$ and TGF- $\beta 3$ have been implicated in large blood vessel injury (33), and TGF- $\beta 2$ is upregulated in JGA cells by renin stimulation $(34,35)$. Therefore, we examined TGF- $\beta 1, \beta 2$, and $\beta 3$ immunostaining. There were no changes in the pattern of TGF- $\beta 1, \beta 2$, or $\beta 3$ isoform staining, making it unlikely that increased TGF- $\beta$ was the cause of the vascular lesions. Other growth factor(s) could have been synthesized locally in response to ACE or AngII ATl receptor blockade. Since AngII induces hypertrophy and hyperplasia in vascular smooth muscle cells (36), it is a potential candidate.

In conclusion, angiotensin II appears to have a direct effect on both glomerular and arteriolar cells in vivo. Additionally, GH mice represent a disease model in which blockade of the RAS has deleterious effects. It may be important to study the molecular basis of AII effect(s) on other forms of glomerulosclerosis, especially those in which AII does not appear to play a major role.

\section{ACKNOWLEDGMENTS}

The authors wish to thank Dr. K. Catt for critical evaluation of this work, Dr. K. Flanders for the TGF- $\beta$ antibodies, and Drs. P. Corvol and J. Gasc for the renin antibody. This study was supported by the Juvenile Diabetes Foundation International (E.P.P., Career Development Award), by the American Diabetic Association (L.J.S., Mentor-based Post-doctoral Fellowship Award), and by the National Institutes of Health (DIR, NIDDK, and Research Grants DK 42131 to A.F., DK 44757 to A.F. and I.I., and DK 37868 to I.I.).

\section{REFERENCES}

1. Lewis EJ, Hunsicker LG, Bain RP, Rohde RD. (1993) The effect of angiotensin-convertingenzyme inhibition on diabetic nephropathy. The Collaborative Study Group. N. Engl. J. Med. 11: 1496-1497.

2. Yoshida Y, Fogo A, Shiraga H, Glick AD, Ichikawa I. (1988) Serial micropuncture analysis of single nephron function in subtotal renal ablation. Kidney Int. 33: 855-867.

3. Yoshida Y, Kawamura T, Ikoma M, Fogo A, Ichikawa I. (1989) Effects of antihypertensive drugs on glomerular morphology. Kidney Int. 36: 626-635.

4. Zatz R, Dunn R, Meyer TW, Anderson S, Rennke HG, Brenner BM. (1986) Prevention of diabetic glomerulopathy by pharmacological amelioration of glomerular capillary hypertension. J. Clin. Invest. 77: 1925-1930.

5. Lafayette RA, Mayer G, Park SK, Meyer TW. (1992) Angiotensin II receptor blockade limits glomerular injury in rats with reduced renal mass. J. Clin. Invest. 90: 766-771.

6. Hall RL, Wilke WL, Fettman M. (1986) The progression of adriamycin-induced nephrotic syndrome in rats and the effect of Captopril. Toxicol. Appl. Pharmacol. 82: 164174.

7. Marinides GN, Groggel GC, Cohen AH, Border WA. (1989) Enalapril and low protein reverse chronic puromycin aminonucleoside nephropathy. Kidney Int. 37: 749-757.

8. Marinides GN, Groggel GC, Cohen AH, Cook T, Baranowski RL, Westenfelder C, Border WA. (1987) Failure of angiotensin converting enzyme inhibition to affect the course of chronic puromycin aminonucleoside nephropathy. Am. J. Pathol. 129: 394-401.

9. Doi T, Striker LJ, Quaife C, Conti FC, Palmiter R, Behringer R, Brinster R, Striker GE. (1988) Progressive glomerulosclerosis develops in transgenic mice chronically expressing growth hormone and growth hormone releasing factor but not in those expressing insulinlike growth factor-1. Am. J. Pathol. 131: 398-403.

10. Yoshida $H$, Mitarai T, Kitamura M, Suzuki T, Ishikawa I, Fogo A, Sakai O. (1994) The effect of selective growth hormone defect in 
the progression of glomerulosclerosis. Am. J. Kidney Dis. 23: 302-312.

11. Yang CW, Striker LJ, Pesce C, Chen WY, Peten EP, Elliot SJ, Doi T, Kopchick JJ, Striker GE. (1993) Glomerulosclerosis and body growth are mediated by different portions of bovine growth hormone: Studies in transgenic mice. Lab. Invest. 68: 62-70.

12. Doi T, Striker LJ, Kimata K, Peten EP, Yamada Y, Striker GE. (1991) Glomerulosclerosis in mice transgenic for growth hormone. increased mesangial extracellular matrix is correlated with kidney mRNA levels. J. Exp. Med. 173: 1287-1290.

13. Peten EP, Striker LJ, Garcia-Perez A, Striker GE. (1992) Glomerulosclerosis in growth hormone transgenic mice, upregulation of $\alpha \mathrm{l}$ (IV) mRNA and appearance of $\alpha \mathrm{l}$ (I) collagen mRNA: Studies by competitive PCR. Kidney Int. 43: S55-S58.

14. Kato H, Suzuki H, Tajima S, Ogata Y, Tominaga T, Sato A, Saruta T. (1991) Angiotensin II stimulates collagen synthesis in cultured vascular smooth muscle cells. J. Hypertens. 9: 17-22.

15. Wolf G, Haberstroh U, Neilson EG. (1992) Angiotensin II stimulates the proliferation and biosynthesis of type I collagen in cultured murine mesangial cells. Am. J. Pathol. 140: 95-107.

16. Ichikawa I, Maddox DA, Cogan MG, Brenner BM. (1978) Dynamics of glomerular ultrafiltration in euvolemic Munich-Wistar rats. Renal Physiol. 1: 121-131.

17. Fuhr J, Kaczmarczyk J, Kruttgen CD. (1955) Eine einfache colorimetrishe Methode zur Inulinbestimmung fur Nieren-clearanceuntersuchungen bei Stoffwechselgesunden und Diabetikern. Klin. Woshenschr. 33: 729730.

18. Smith HW, Finkelstein N, Aliminosa L, Crawford B, Graber M. (1945) The renal clearances of substituted hippuric acid derivatives and other aromatic acids in dog and man. J. Clin. Invest. 24: 388-404.

19. Flanders KC, Roberts AB, Ling N, Fleurdelys BE, Sporn MB. (1988) Antibodies to peptide determinants in transforming growth factor beta and their applications. Biochemistry 27: 739-746.

20. Pesce CM, Striker LJ, Peten EP, Elliot S, Striker GE. (1991) Glomerulosclerosis at both early and late stages is associated with increased cell turnover in mice transgenic for growth hormone. Lab. Invest. 65: 601605.

21. Dehoff RT, Rhines FN. (1968) Method of estimating size of discrete objects. In Quantitative Microscopy. McGraw-Hill Co., New York, pp. 75.

22. Peten EP, Garcia-Perez A, Terada Y, Woodrow D, Martin BM, Striker GE, Striker LJ. (1992) Age related changes in 1 and 2 type IV collagen mRNAs in adult mouse glomeruli: Quantitation by competitive PCR. Am. J. Physiol. 263: F951-F957.

23. Carome MA, Striker LJ, Peten EP, Elliot SJ, Stetler-Stevenson WG, Reponen P, Tryggvason K, Striker GE. (1994) Assessment of 72 $\mathrm{kDa}$ gelatinase and tissue inhibitor of metalloproteinase-1 (TIMP-1) gene expression in normal and sclerotic murine glomeruli in vivo. J. Am. Soc. Nephrol., in press.

24. Anderson S, Diamond JR, Karnowsky MJ, Brenner BM. (1988) Mechanisms underlying transition from acute glomerular injury to late glomerular sclerosis in a rat model of nephrotic syndrome. J. Clin. Invest. 82: 17571768.

25. Rosenberg ME, Smith LJ, Correa-Rotter R, Hostetter TH. (1994) The paradox of the renin-angiotensin system in chronic renal disease. Kidney Int. 45: 403-410.

26. Anderson S, Rennke HG, Brenner BM. (1986) Therapeutic advantages of converting enzyme inhibitors in arresting progressive renal disease associated with systemic hypertension in the rat. J. Clin. Invest. 77: 19932000.

27. Kakinuma Y, Kawamura T, Bills T, Yoshioka T, Ichikawa I, Fogo A. (1992) Blood pressure-independent effect of angiotensin inhibition on vascular lesions of chronic renal failure. Kidney Int. 42: 46-55.

28. Ikoma M, Kawamura T, Kakinuma Y, Fogo A, Ichikawa I. (1991) Cause of variable therapeutic efficiency of angiotensin converting enzyme inhibitor on the glomerular mesangial lesion. Kidney Int. 40: 192-202.

29. Sorbi D, Fadly $M$, Hicks R, Alexander S, Arbeit L. (1993) Captopril inhibits the 72 $\mathrm{kDa}$ and $92 \mathrm{kDa}$ matrix metalloproteinases. Kidney Int. 44: 1266-1272.

30. Ichikawa I, Harris RC. (1991) Angiotensin actions in the kidney: Renewed insight into the old hormone. Kidney Int. 40: 583-596.

31. Johnson RJ, Alpers CE, Yoshimura A, Lombardi D, Pritzl P, Floege J, Schwartz SM. (1992) Renal injury from angiotensin II- 
mediated hypertension. Hypertension 19: 464-474.

32. Hunt MK, Ramos SP, Geary KM, Norling LL, Peach MJ, Gomez RA, Carey RM. (1992) Colocalization and release of angiotensin and renin in renal cortical cells. Am. J. Physiol. 263: F363-F373.

33. Majesky MW, Lindner V, Twardzik DR, Schwartz SM. (1991) Production of transforming growth factor beta 1 during repair of arterial injury. J. Clin. Invest. 88: 904-910.

34. Horikoshi S, McCune BK, Ray PE, Kopp JB, Sporn MB, Klotman PE. (1991) Water depri- vation stimulates transforming growth factor beta 2 accumulation in the juxtaglomerular apparatus of mouse kidney. J. Clin. Invest. 88: 2117-2122.

35. Ray PE, McCune BK, Gomez RA, Horikoshi S, Kopp JB, Klotman PE. (1993) Renal vascular induction of TGF-beta 2 and renin by potassium depletion. Kidney Int. 44: 10061013.

36. Re RN. (1987) Cellular mechanisms of growth in cardiovascular tissue. Am. J. Cardiol. 60: 1041-1091. 